\title{
More than one inseminated female in colonies of the independent-founding wasp Mischocyttarus cassununga von Ihering (Hymenoptera, Vespidae)
}

\author{
André S. N. Murakami ${ }^{1}$, Sulene N. Shima² \& Ivan C. Desuó ${ }^{1}$
}

\begin{abstract}
${ }^{1}$ Programa de Pós-Graduação em Zoologia, Departamento de Zoologia, Universidade Estadual Paulista, 13506-900 Rio Claro-SP, Brazil sunamigobio@yahoo.com.br; ivan.desuo@yahoo.com.br

²Departamento de Zoologia, Instituto de Biociências, 13506-900 Rio Claro-SP, Brazil. sulenens@rc.unesp.br
\end{abstract}

\begin{abstract}
More than one inseminated female in colonies of the independent-founding wasp Mischocyttarus cassununga von Ihering (Hymenoptera, Vespidae). In the primitively eusocial wasps, especially Polistini and Mischocyttarini tribes, the physiological condition of each individual is strongly associated with its dominance status in the colonial hierarchy. As a rule, in independent-founding wasps, female wasps are all morphologically alike, and their role is apparently quite flexible even as adults. However, some studies have shown that differences in body size can exist between reproductive and non-reproductive females. Thus, the present study aimed at detecting differences between reproductive (inseminated) and non-reproductive (uninseminated) individuals based on morphological and physiological parameters. We taperecorded the daily behavioural repertory of six colonies of Mischocyttarus cassununga for determining the hierarchical dominance in the field, and then collected these colonies (in different cycle stages) for measuring 13 set characters, and assessing the physiological condition of each individual by inspecting their fat bodies and ovaries. Our results revealed that inseminated and uninseminated females are not significantly different in relation to body size, in spite of first group shows higher average than second in almost all measured parts. The physiological evaluation of each individual demonstrated more than one inseminated female per colony during all stages of the colony cycle, suggesting a strategic condition of this species against difficulties (predation and parasitism of the colony) in nature.
\end{abstract}

KEYWORDS. Dominance; social hierarchy; morphometry; physiology; Mischocyttarini.

\begin{abstract}
RESUMO. Mais de uma fêmea inseminada nas colônias da vespa de fundação independente Mischocyttarus cassununga von Ihering (Hymenoptera, Vespidae). Nas vespas eussociais basais, especificamente nas tribos Polistini e Mischocyttarini, a condição fisiológica de cada indivíduo é fortemente associada com o seu status de dominância na hierarquia colonial. Como regra, nas vespas de fundação independente, as fêmeas são morfologicamente semelhantes, e suas funções são aparentemente bastante flexíveis quando adultas. Entretanto, alguns estudos têm demonstrado que diferenças no tamanho corpóreo podem existir entre as fêmeas reprodutivas e não reprodutivas. Desse modo, o objetivo do presente estudo foi detectar diferenças entre fêmeas consideradas reprodutivas (inseminadas) e não reprodutivas (não inseminadas) baseandose em parâmetros morfológicos e fisiológicos. O repertório comportamental de seis colônias de Mischocyttarus cassununga foi observado diariamente no campo com a ajuda de uma filmadora, e em seguida, todas as colônias em diferentes fases do ciclo foram coletadas para a mensuração de 13 caracteres e análise da condição fisiológica (quantidade de corpo gorduroso e grau de desenvolvimento ovariano) de cada uma das fêmeas. Nossos resultados revelaram que as fêmeas inseminadas e não inseminadas não são significantemente diferentes em relação ao tamanho do corpo, apesar do primeiro grupo apresentar uma média maior do que o segundo em quase todas as regiões corpóreas medidas. A análise fisiológica de cada indivíduo demonstrou a presença de mais de uma fêmea inseminada por colônia durante todas as fases do ciclo colonial, sugerindo uma condição estratégica desta espécie frente às dificuldades (predação e parasitismo da colônia) na natureza.
\end{abstract}

PALAVRAS-CHAVE. Dominância; fisiologia; hierarquia social; morfometria; Mischocyttarini.

The relation between social behaviour and physiology has been analyzed in detail in independent-founding wasps (reviewed in Markiewicz \& O'Donnell 2001). The queen is the female in the nest presenting the most prominently developed ovary, and it usually dominates all the other females (workers) through agonistic behaviours, extensively monopolizing the reproductive yield of the colony (Pardi 1948; Jeanne 1972; Strassmann \& Meyer 1983; O'Donnell 1998a, b). Consequently, very often the ovarian development of the subordinate workers is negatively affected by this action of the dominant female (functional queen) (Pardi 1948; Richards \& Richards 1951). This way, as other studies have shown (Pardi 1948; Röseler et al. 1985), the hierarchical position of a wasp frequently depends on its reproductive physiology - i. e. the condition of dominance obtained by a female apparently triggers some physiological reaction that influences its ovarian development (Wheeler 1986).

Markiewicz \& O'Donnell (2001) suggested that alterations in nutritional physiology are determined by differences in task performance. The fat body was demonstrated to be of great importance to understand the particularities of each caste (Röseler 1991), mainly because it is the principal tissue for storing energy (Paes de Oliveira 2005). Additionally, numerous studies have considered and employed the inseminated state as the main criterion for distinguishing queens from workers (Richards \& Richards 1951; Shima et al. 1994, 1996a, b; 
O’Donnell 1998a; Shima et al. 1998, 2000a, b). Wheeler (1996) found that oogenesis can be regulated by several key factors in a social context: nutrition, degree or nature of activity, mating, season, and conspecifics.

As a rule, castes of independent-founding wasps are not morphologically different, with queens and workers differing in their tasks in the colony (Jeanne 1986; Keeping 2000). On the other hand, recent studies with independent-founding wasps showed that the reproductive or non-reproductive condition of a female may be correlated with differences in body size and/or physiological state (Gobbi et al. 2006; Fukuda et al. 2003; Tannure-Nascimento et al. 2005; Murakami \& Shima 2006). Additionally O'Donnell (1998a) claimed that studies based on measurements of the relative size and shape of structures of the three body sections - head, mesosoma, and metasoma - are necessary for a detailed comparison between queens and workers of the independent-founding wasps.

The genus Mischocyttarus is composed by a vast diversity of species; however, there are a few studies about these fascinating wasps. Although M. cassununga is characterized by the presence of only one reproductive dominant female per colony (Richard 1971, 1978), this work shows that colonies of this species present more than one inseminated female during their cycles, and as a consequence females of hierarchical higher positions probably take part in the colonies' reproductive yield. In the present work, we aimed to analyse the species $M$. cassununga by using a morpho-physiological approach.

\section{MATERIAL \& METHODS}

Six colonies in the post-emergence phase (four colonies in pre-male substage: 1, 2, 3, 4; and two colonies in post-male substage: 5 and 6) (Table I) were studied in the campus of Universidade Estadual Paulista - Rio Claro, Brazil (22 24'26"S, 47033'36"W).

The ontogenetic stages of each colony were determined by checking daily both the immature forms present and the total number of adult wasps in the nest. Each wasp was individually marked with modeling acrylic paint over the mesoscutelum. All cells of the each colony are numbered for following the development of immature individuals. This allowed us to know the age of each wasp of colonies, except the age of the females already present in the colonies at the beginning of the observations. During $60 \mathrm{~min}$ each day, and whenever possible between 8:00h-12:00h or 13:00-17:00h, all the behaviours in the colonies were videotaped with a SonyDCR-TRV17 hand camera.

Determination of social hierarchy. The dominance status of each female in the colony was determined based on the frequency of displayed agonistic behaviours, and determined by the method of linearization of Premnath et al. (1990). This method allowed to calculate the dominance index (Id) for each member of a colony according to the following formula:

$$
\begin{aligned}
& \text { n } m \text { n n } \quad p \text { n } \\
& \text { Id }=\Sigma \text { Bi }+\Sigma \Sigma b j i+1 / \Sigma L i+\Sigma \Sigma l j i+1 \\
& \mathrm{i}=1 \quad \mathrm{j}=1 \mathrm{i}=1 \quad \mathrm{i}=1 \quad \mathrm{j}=1 \mathrm{i}=1
\end{aligned}
$$

Bi corresponds to the total of the frequencies when a subject dominated other members of the colony; bji is the total of the frequencies indicating when the individuals dominated by a subject dominated, in their turn, other members of the colony; " 1 to $\mathbf{m}$ " indicates the total number of individuals dominated by the subject; $\mathbf{L i}$ is the total of the frequencies indicating that the subject was dominated by the other members of the colony; lji is the total of the frequencies indicating the individuals who dominated the subject and who, in their turn, were dominated by other members of the colony; and "1 to p" indicates the total number of individuals who dominated the subject.

Morpho-physiological analysis. Once the field observations were finished, all colonies were collected: each one was anesthetized with ethyl acetate, and directly fixed in Dietrich's solution. Past 72 hours, each colony was then transferred to alcohol $70 \%$.

From each colony, each individual wasp was measured under a stereomicroscope for the following 13 characters (further details in Fig. 1):

Head: HW - head width; IDm - minimum interorbital distance Mesosoma: MSL - mesoscutum length; MSW mesoscutum width; MEL - mesoscutellum length Metasoma: $\mathrm{T}_{1} \mathrm{BH}$ - metasomal tergite I basal height; $\mathrm{T}_{1} \mathrm{TH}$ - metasomal tergite I top height; $\mathrm{T}_{1} \mathrm{~L}$ - metasomal tergite I length; $\mathrm{T}_{3} \mathrm{~W}$ metasomal tergite III width; $\mathrm{T}_{3} \mathrm{H}$ - metasomal tergite III height; $\mathrm{T}_{4} \mathrm{~W}$ - metasomal tergite IV width; $\mathrm{T}_{4} \mathrm{H}$ - metasomal tergite IV height (width and height of these tergites was measured with them positioned between glass slides).

Right wing: WL - right wing length Those characters were chosen based on Shima (1991) and Shima et al. (2000a).

After taking the measurements, the wasps were depicted in a WILD-Leica light chamber. Based on these drawings the following factors intrinsic to reproductive development were evaluated:

Ovary development: To evaluate the ovarian degree of development of each individual, we based on our previous study made in this same species (Fig. 2: Murakami \& Shima 2006).

Spermatheca content: We separated inseminated from uninseminated females based on the relative opacity of the spermathecae, also checking for the presence of a rounded compact mass, as was efficiently done in previous studies (Shima et al. 1994, 1996 a, b; Shima et al. 1998, 2000a, b, 2003; Noda et al. 2003).

Relative quantity of fat: This was visually estimated by comparison, i.e. females were divided in four groups: $25 \%$; $50 \% ; 75 \%$ and $100 \%$. Based on this, it was possible to correlate the physiological status with the kind of task in the colony of each female according to its age.

Statistical analysis. The morphometric data were $\log$ transformed for the adequacy of normality. A stepwise Discriminant Analysis (Zar 1999) was applied to the 13 morphological characters with the main objective of comparing inseminated females with uninseminated ones.

The colonies were grouped according to the colonial cycle 

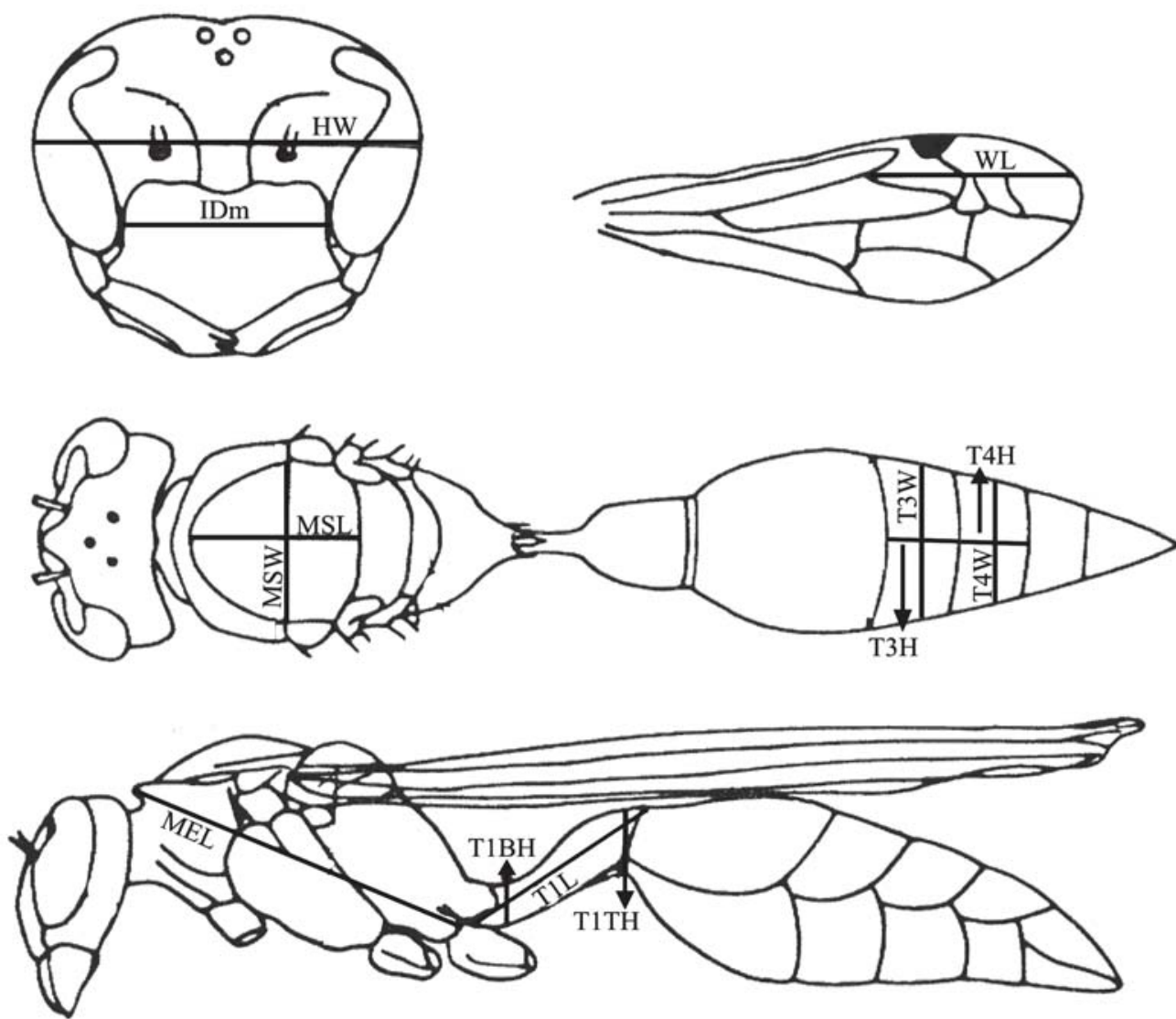

Fig. 1. Representatives measures for morphometric analysis: head width (HW); minimum interorbital distance (IDm); mesoscutum length (MSL); mesoscutum width (MSW) mesoscutellum length (MEL); metasomal tergite I basal height ( $\left.\mathrm{T}_{1} \mathrm{BH}\right)$; metasomal tergite $\mathrm{I}$ top height ( $\left.\mathrm{T}_{1} \mathrm{TH}\right)$; metasomal tergite I length $\left(\mathrm{T}_{1} \mathrm{~L}\right)$; metasomal tergite III width $\left(\mathrm{T}_{3} \mathrm{~W}\right)$; metasomal tergite III height $\left(\mathrm{T}_{3} \mathrm{H}\right)$; metasomal tergite IV width $\left(\mathrm{T}_{4} \mathrm{~W}\right)$; metasomal tergite IV height $\left(\mathrm{T}_{4} \mathrm{~W}\right)$; and right wing length (WL). Based on Shima et al. (2000).

substage (pre-male and post-male) for detecting variations according to the colonial stage of development. In the preemergence stage it was impossible comparing inseminated and uninseminated females because all nests were founded by a single female (haplometrosis). Consequently, based on the comparison between the two groups of females, we hoped to clarify characters that can help discern inseminated from uninseminated females in M. cassununga.

\section{RESULTS}

Establishment of social hierarchy. According behaviours of dominance and subordination, our results show the presence of a stable linear hierarchy during the pre- and postmale substages. The dominant female of the social hierarchy achieves a highest value of dominance index (Id) in relation to other females of colony, i.e. it was the most aggressive female in the colony (Fig. 3). The female which occupied the second position in the ranking showed the second highest value of Id, and so forth. The individuals just below the dominant female in the social ranking were considered females of higher hierarchically positions and called of the sub-dominant females. The females which showed a lower value of dominance index were considered subordinate females.

Morphometric analysis of the different substages. The measurements of 13 characters revealed that inseminated females tend to be slightly larger than uninseminated females in almost all body parts, except to T1BH, T3W in the pre-male substage and HW, T1BH, T1TH in the post-male substage (Table II). Despite these differences of averages between two groups the Discriminant Analysis shows that these differences are not significant (Table III). Wilks' lambda values were close to 1 . Furthermore, predicted vs observed classifications, based on discriminant analysis, show that inseminated groups are not well defined as uninseminated females (Table IV). The dominant female of colony 5 was not analysed by morphophysiological aspects because it disappeared before the collection.

Degree of ovarian development, insemination, relative quantity of fat body, and age during the colony cycle. The results demonstrate that the ovaries of inseminated females were more developed than those of uninseminated ones during the pre- and post-male substages (Figs. 4 and 5). Regarding the colony cycle, the total number of wasps with welldeveloped ovaries (patterns A and B) was greater in the premale than in the post-male substage. 

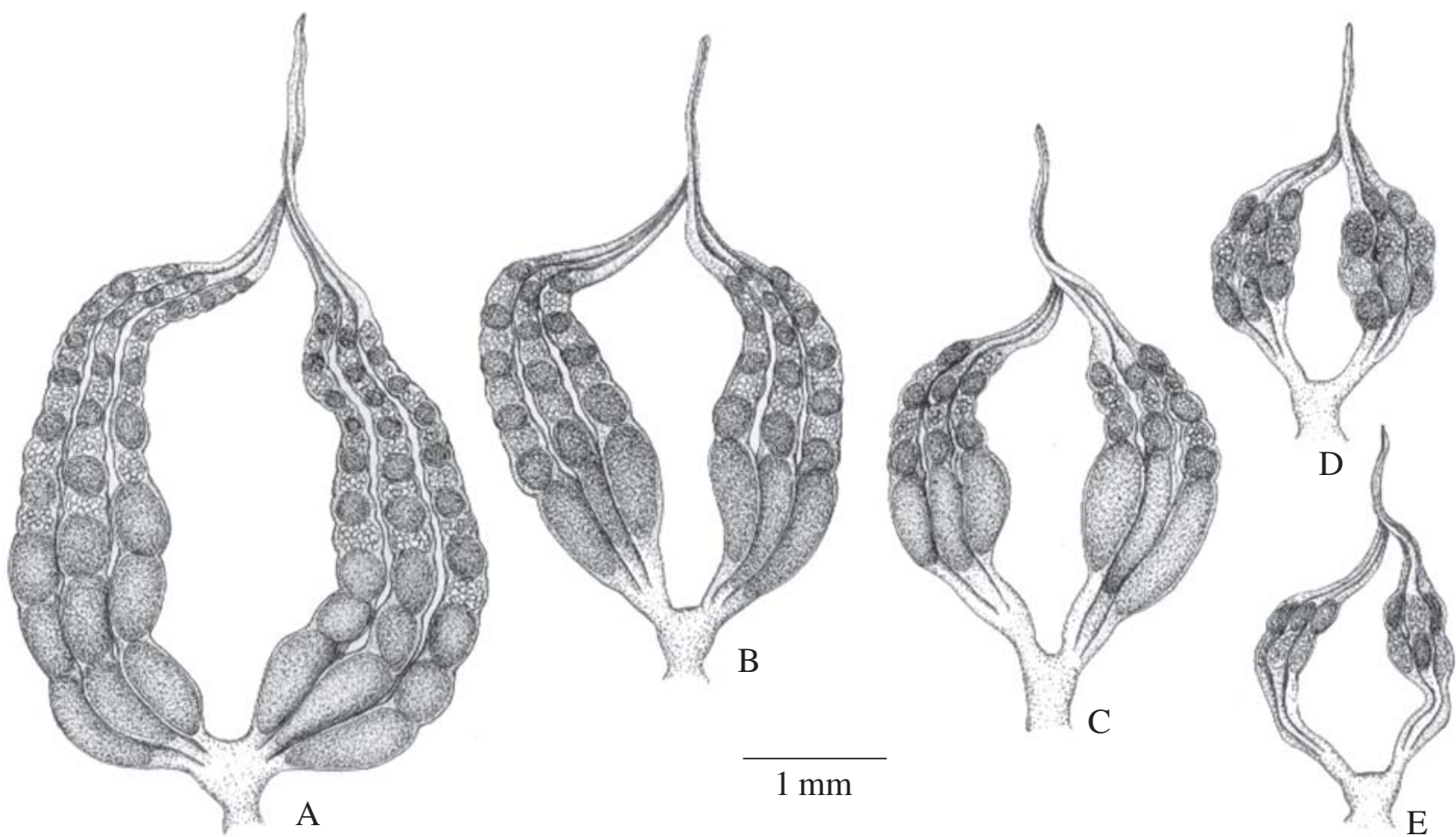

Fig. 2. Pattern of ovarian development in Mischocyttarus cassununga (Adapted from MURAKAMI and SHIMA 2006). (ovary A $=$ very developed, ovaries $\mathrm{B}$ and $\mathrm{C}=$ developed enough, ovary $\mathrm{D}=$ moderately developed and ovary $\mathrm{E}=$ little developed).

All ovaries examined exhibited at least some degree of development and neither filamentous nor atrophic ovaries were found (Figs. 4 and 5). This can indicates that the dominant females of $M$. cassununga are not capable of inhibiting the development of their subordinates ' ovaries (sub-dominant females) and, consequently, subordinate females (presenting ovaries in patterns D or E) did not completely lose their reproductive capacity.

Regarding the analysis of the contents of the spermathecae, our dissections revealed that there was always more than one inseminated female (dominant female and subdominant females) per colony during all colony cycle (Figs. 4 and 5). Furthermore, our results show that sub-dominant females are daughters of dominant female in the colony 2 (Fig. 4). The inseminated females with well-developed ovaries (dominant and sub-dominant females which already present in the colony at the beginning of the observations) were the oldest in the nests, while most subordinates (females which emerged from its colonies, respectively) were the youngest (Figs. 4 and 5). Still on the subordinate wasps, among all that were collected during the post-male substage (from colonies $\mathrm{Bc} 1$ and S3), only three wasps from colony Bc1 (aged 38, 41, and 42 days) were older than sub-dominant females of the same colony (age ranging 11-34 days). All the other subordinates were younger than the dominant females.

Although the dominant female and sub-dominant females presented much fat body and well-developed ovaries (inseminated ones with patterns A or B from pre- and postmale substage colonies) some subordinate females of lower hierarchically positions with less developed ovaries also presented great quantity of fat body (uninseminated females with pattern $\mathrm{C}$ from pre-male and $\mathrm{E}$ condition in post-male substages) (Figs. 4 and 5). The dominant female of colony 6 with developed ovary exhibited little relative quantity of fat body in the post-male substage.

Oviposition during the substages of the colonial cycle.

Table I. Stage, substage, number of collected wasps, period and time of observation of collected colonies in Mischocyttarus cassununga.

\begin{tabular}{|c|c|c|c|c|c|c|c|}
\hline \multicolumn{2}{|c|}{ Colony ontogeny } & \multirow[t]{2}{*}{ Nest } & \multirow{2}{*}{$\begin{array}{l}\text { Number of } \\
\text { adult wasps }\end{array}$} & \multirow{2}{*}{$\begin{array}{c}\text { Number of } \\
\text { Inseminated females }\end{array}$} & \multicolumn{2}{|c|}{ Observation } & \multirow[t]{2}{*}{ Year } \\
\hline Stage & Substage & & & & Period & Time (hours) & \\
\hline \multirow[t]{6}{*}{ Post-emergence } & Pre-male & 1 & 10 & 3 & $22 / 03$ to $23 / 06$ & 39.25 & 2004 \\
\hline & & 2 & 11 & 3 & $13 / 08$ to $08 / 11$ & 25.9 & \\
\hline & & 3 & 6 & 2 & $06 / 04$ to $06 / 05$ & 36 & 2005 \\
\hline & & 4 & 7 & 3 & $15 / 06$ to $23 / 08$ & 70 & \\
\hline & Post-male & 5 & 29 & 6 & $13 / 07$ to $22 / 12$ & 11 & 2004 \\
\hline & & 6 & 23 & 7 & $16 / 05$ to $01 / 08$ & 12.1 & 2005 \\
\hline
\end{tabular}




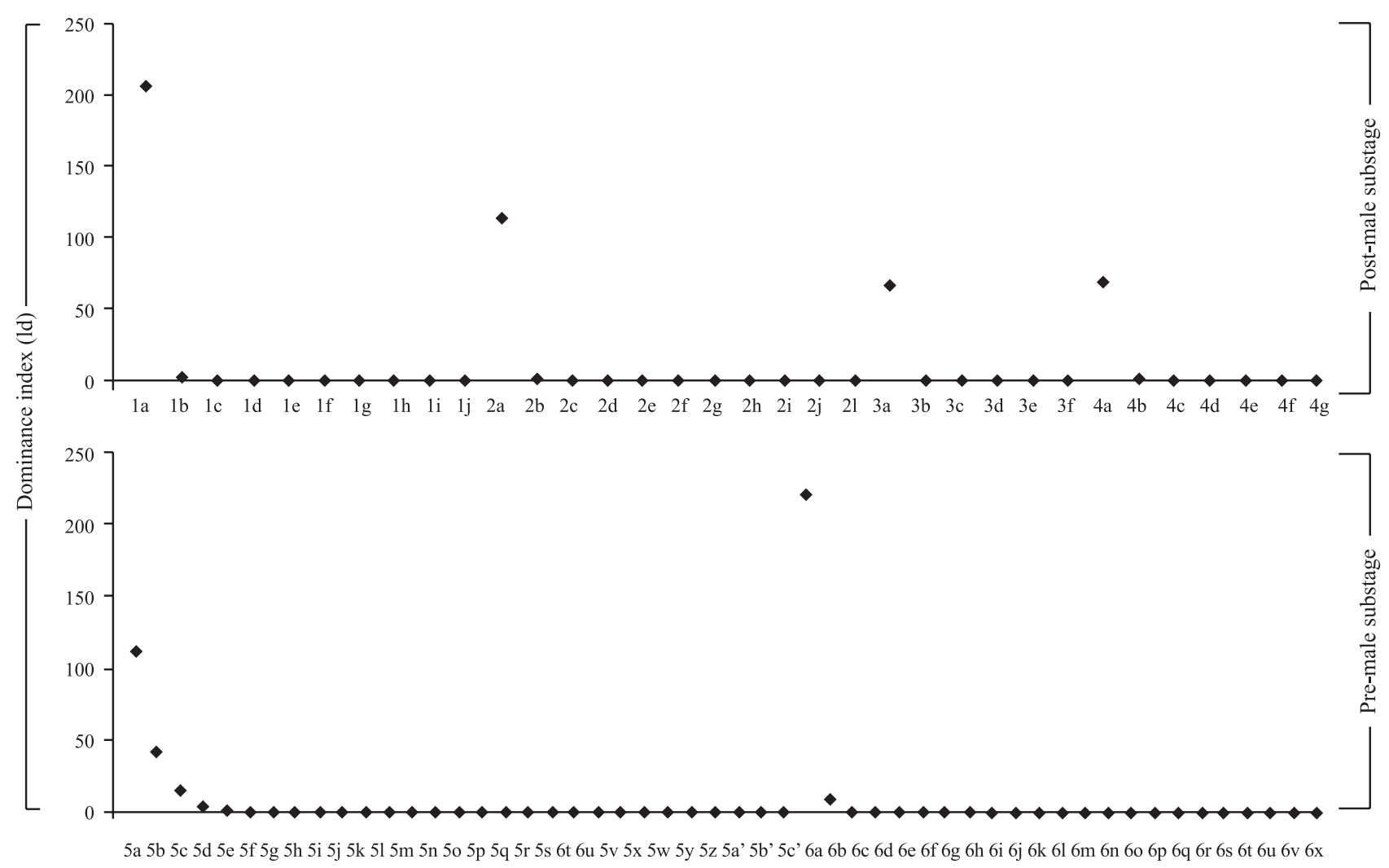

Fig. 3. Dominance index (Id) of each individual from colonies 1, 2, 3, 4 in the pre-male substage and 5 and 6 in the post-male substage.

Our results revealed that more than one inseminated female can lay eggs in the same colony during all colony cycle (Table V). Particularly, the whole development of two eggs oviposited by two sub-dominant females (from colony $\mathrm{Bc} 1$ ) were observed, and consequently, two male wasps emerged. The emergence of males indicates that these females (which were namely verm and amv) probably had not been inseminated prior to oviposition. The remaining eggs in this colony were either destroyed by parasitism (by ichneumonids or by the fly Megaselia scalaris Loew, 1866), and during the reproductive competition between dominant and sub-dominant females, probably by differential oophagy. The occurrence of differential oophagy was noted during the mapping of nests when the disappearance of eggs or change in its position occurred.

\section{DISCUSSION}

Morphometry. Until recently, it was thought that there were no morphological differences among adult wasps of independently founded colonies of Polistinae. On the other hand, some previous studies have shown that there are differences in body size between reproductive and nonreproductive females of independent-founding wasps (Gobbi et al. 2006 with Polistes versicolor Olivier, 1791; TannureNascimento et al. 2005 with Polistes satan Bequaert, 1940; Fukuda et al. 2003 with Ropalidia plebeiana Richards, 1978). Through Discriminant Analysis we did not detect significant morphological differences between the inseminated and uninseminated females during pre- and post-male substages. However, despite these results we suggest the presence of a potential difference pronounced at the gaster, mainly pertaining the height of the metasomal tergite III $\left(\mathrm{T}_{3} \mathrm{H}\right)$ (Table III). We

Table II. Measurements $(\mathrm{X} \pm \mathrm{SD}$ ) of 13 morphological characters (HW - head width; IDm - minimum interorbital distance; MSL - mesoscutum length; MSW - mesoscutum width; MEL - mesoscutellum length; $\mathrm{T}_{1} \mathrm{BH}$ - metasomal tergite I basal height; T, TH - metasomal tergite I top height; $\mathrm{T}_{1} \mathrm{~L}$ - metasomal tergite I length; $\mathrm{T}_{3} \mathrm{~W}$ - metasomal tergite III width; $\mathrm{T}_{3} \mathrm{H}$ - metasomal tergite III height; $\mathrm{T}_{4} \mathrm{~W}$ - metasomal tergite IV width; $\mathrm{T}_{4} \mathrm{H}$ - metasomal tergite IV height; WL - right wing length) of the inseminated females (I) and uninseminated females (NI) from colonies in the pre-male and post-male substages of $M$. cassununga.

\begin{tabular}{cccccc}
$\begin{array}{c}\text { Substage } \\
\text { Measured }\end{array}$ & \multicolumn{2}{c}{ Pre-male } & & \multicolumn{2}{c}{ Post-male } \\
\cline { 6 - 7 } \cline { 5 - 6 } characters & $\mathrm{I}(\mathrm{n}=11)$ & $\mathrm{NI}(\mathrm{n}=23)$ & & $\mathrm{I}(\mathrm{n}=13)$ & $\mathrm{NI}(\mathrm{n}=39)$ \\
\hline HW & $2.73 \pm 0.14$ & $2.69 \pm 0.15$ & & $2.59 \pm 0.05$ & $2.59 \pm 0.08$ \\
IDm & $1.10 \pm 0.06$ & $1.08 \pm 0.08$ & & $1.07 \pm 0.03$ & $1.06 \pm 0.04$ \\
MSL & $1.84 \pm 0.13$ & $1.81 \pm 0.13$ & & $1.81 \pm 0.06$ & $1.81 \pm 0.09$ \\
MSW & $1.81 \pm 0.10$ & $1.77 \pm 0.12$ & & $1.80 \pm 0.06$ & $1.77 \pm 0.09$ \\
MEL & $4.15 \pm 0.22$ & $4.06 \pm 0.26$ & & $4.05 \pm 0.15$ & $3.98 \pm 0.24$ \\
T1BH & $0.36 \pm 0.03$ & $0.37 \pm 0.04$ & & $0.35 \pm 0.02$ & $0.35 \pm 0.02$ \\
T1TH & $0.68 \pm 0.08$ & $0.66 \pm 0.05$ & & $0.64 \pm 0.04$ & $0.64 \pm 0.04$ \\
T1L & $2.58 \pm 0.16$ & $2.56 \pm 0.18$ & & $2.57 \pm 0.09$ & $2.53 \pm 0.14$ \\
T3W & $4.17 \pm 0.19$ & $4.18 \pm 0.29$ & & $4.07 \pm 0.16$ & $4.01 \pm 0.17$ \\
T3H & $1.77 \pm 0.15$ & $1.69 \pm 0.16$ & & $1.75 \pm 0.09$ & $1.68 \pm 0.11$ \\
T4W & $3.99 \pm 1.91$ & $3.97 \pm 0.27$ & & $3.86 \pm 0.14$ & $3.83 \pm 0.16$ \\
T4H & $1.53 \pm 0.11$ & $1.48 \pm 0.10$ & & $1.48 \pm 0.08$ & $1.45 \pm 0.07$ \\
WL & $4.00 \pm 0.19$ & $3.94 \pm 0.23$ & & $3.85 \pm 0.10$ & $3.80 \pm 0.16$ \\
\hline
\end{tabular}



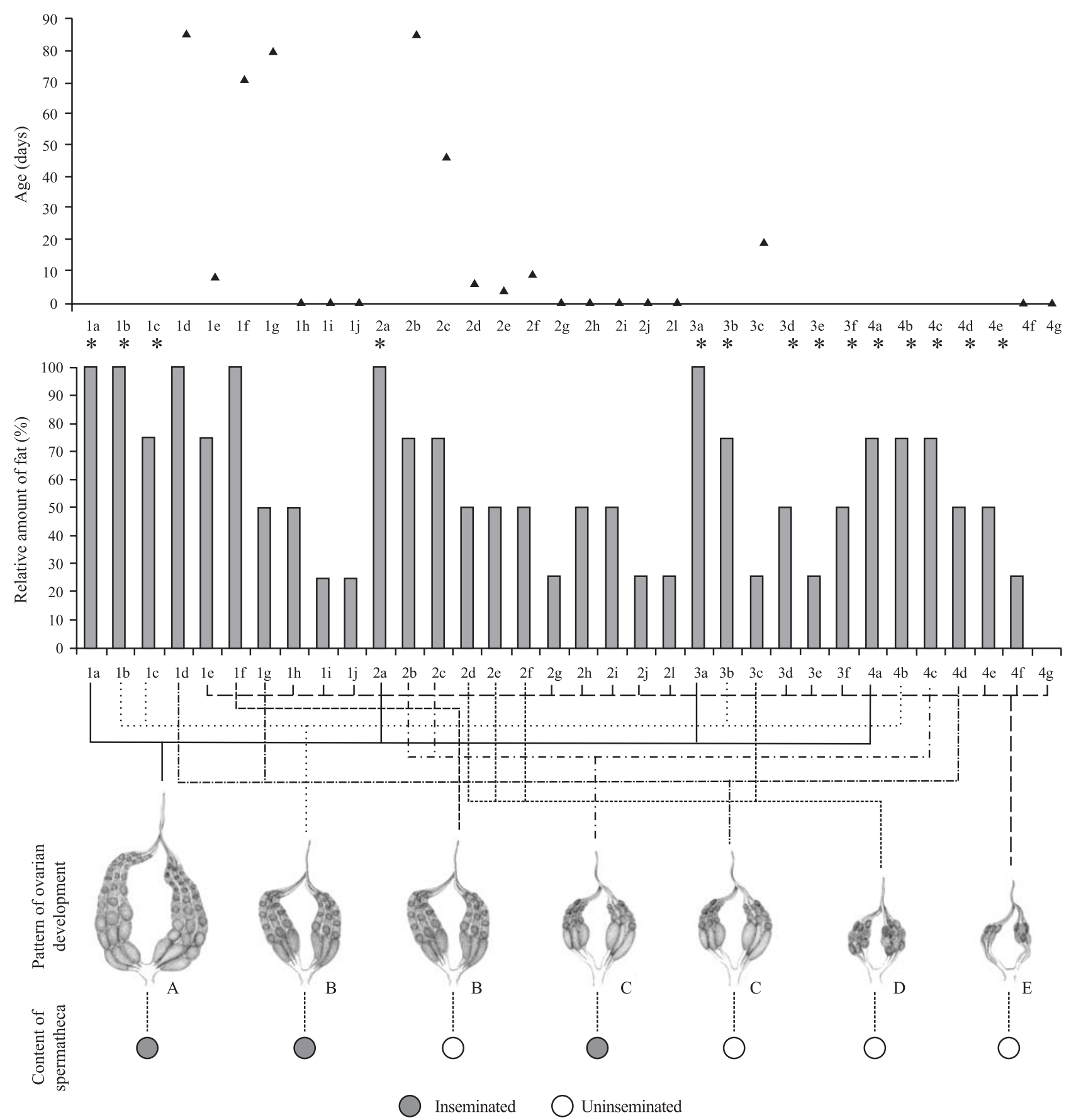

Fig. 4. Age (in days), relative amount of fat, pattern of ovarian development and spermatheca content of each individual from colonies $1,2,3$ and 4 of $M$. cassununga during the pre-male substage. * Age not determined: presence on the nest at beginning of observation. $0-$ Individuals emerged after colonies collection.

think this might be related to pattern of ovarian development, as reported by Murakami \& Shima (2006) to happen with the same species. Thus, indicating that greater body size in $M$. cassununga can aid the wasps achieve social / reproductive dominance, but it is probably of secondary relevance in face of hormonal and nutritional traits, as related by Keeping (2000) in Belonogaster petiolata Degeer, 1778.

Physiological aspects. In several independent-founding wasps the production of eggs by subordinates is apparently not wholly suppressed, but takes place at different rates according to their hierarchical rank (Pardi 1948; Litte 1977, 1979, 1981; West-Eberhard 1986; Suzuki 1987; Röseler 1991). For example, in Mischocyttarus mexicanus de Saussure, 1854 (Litte 1977) and M. labiatus Fabricius, 1804 (Litte 1981), nonegg-laying foundresses lay eggs inside the nest cells immediately after the natural disappearance or removal of the queen. Our results show that the inhibition of ovary does not happen in M. cassununga and also that the dominant female 

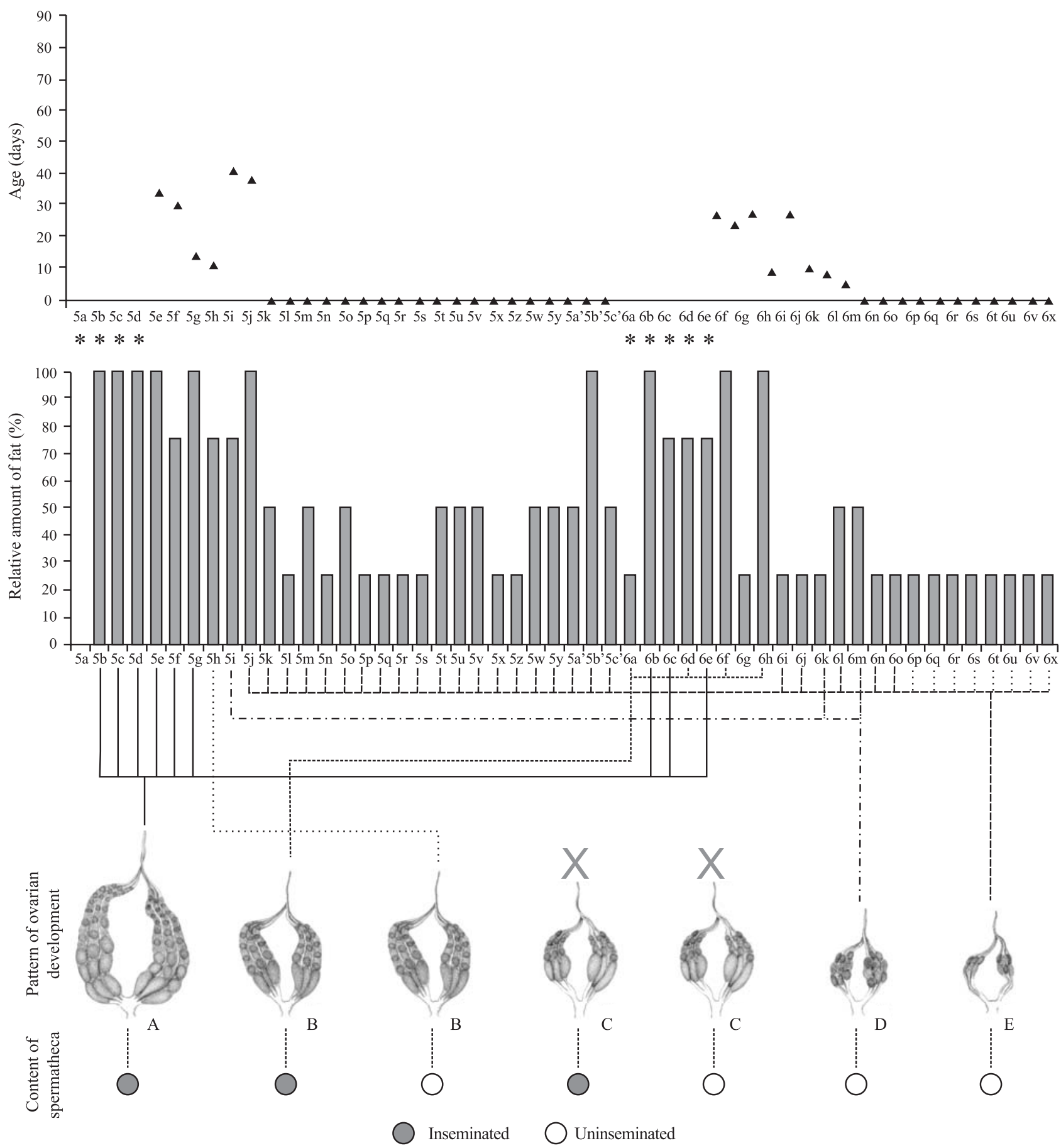

Fig. 5. Age (in days), relative amount of fat, pattern of ovarian development and spermatheca content of each individual from colonies 5 and 6 of $M$. cassununga during the post-male substage. * Age not determined: presence on the nest at beginning of observation. $0-$ Individuals emerged after colonies collection.

of this species is apparently tolerant to the presence of other potential reproductive females (sub-dominant females) in a same colony. Interestingly, the number of inseminated females and females with well-developed ovaries even increased during the colony cycle (Figs. 4 and 5). Similar results were observed in Polistes annularis Linnaeus, 1763 by Strassmann (1983) and in Ropalidia marginata Dover and Rao, 1922 and
R. cyathiformis van der Vecht, 1941 by Deshpande et al. (2006). We suggest that the presence of more than one inseminated female in the same colony might be beneficial to the nest cycle in the present species, since when the queen disappears or dies the colony would ultimately be doomed without another wasp capable of superseding it.

According to Simões et al. (1985), of all species of the 
Table III. Discriminant morphometric variables between inseminated and uninseminated females of Mischocyttarus cassununga in the pre(Number of variables in the model: 2; Wilks' lambda: 0.9095 approx. $F=1.5425, p<0.2298$ ) and post-male (Number of variables in the model: 3; Wilks' lambda: 0.8151 approx. $F=3.6302, p<0.0193$ ) substages using the stepwise procedure.

\begin{tabular}{llll}
\hline Pre-male & Wilks' lambda & F-remove (1.31) & p-level \\
\hline T3H & 0.9999 & 3.0847 & 0.0889 \\
T3W & 0.9501 & 1.3846 & 0.2482 \\
Post-male & Wilks' lambda & F-remove (1.48) & p-level \\
T3H & 0.8970 & 4.8283 & 0.0328 \\
MSL & 0.9126 & 5.7437 & 0.0204 \\
MSW & 0.8715 & 3.3234 & 0.0745
\end{tabular}

Original data are based in millimeters.

genus Mischocyttarus occurring in the vicinities of Rio Claro, $M$. cassununga is the most abundant one, suggesting some local adaptation edge in relation to the others $M$. drewseni, $M$. cerberus styx Richards, 1940, and M. montei Zikàn, 1949, most markedly during the cold periods. We think there that the great plasticity of behaviour in independent-founding wasps, as described by Litte $(1979,1981)$ with Mischocyttarus flavitarsis Saussure, 1854 and M. labiatus, respectively, coupled with the presence of more than one inseminated wasp per colony in M. cassununga (Murakami \& Shima 2006) may account for the predominance of this species in this area, which is observed until recent days (personal observation).

Wheeler (1994) once said that an increment of fat tissue precedes the development of oocytes, and that these display intense metabolic activity during the process of posture, mainly by producing vitellogenin. Shima et al. (2003) observed that some workers of Protonectarina sylveirae de Saussure, 1854 presented more fat body than the queens. Through the comparison between figs. 4 and 5, we could verify that subdominant females of $M$. cassununga, with more developed ovaries, showed a nutritional superavit illustrated by a higher quantity of fat body. Uninseminated co-foundress with undeveloped ovaries presented little fat body. On the other hand, Wheeler (1996) also proposed that the oogenesis in a social context could be regulated by several factors, such as nutrition, activity, mating, season, and conspecifics. Staurengo da Cunha \& Cruz-Landim (1983) claimed that the ovaries of queens of Atta sexdens rubropilosa Forel, 1908 had grown on resources previously stored in the fat body for observing that it decreased in volume with age, while the ovaries developed to their maximum. Murakami \& Shima (2006) suggested based on similar findings that females of higher hierarchical position (dominant and sub-dominant females) are expected to have less fat (energy reserve) than others lower in the hierarchy of M. cassununga. However, the results of our present study indicate that the quantity of fat in these inseminated females could be diminished with age (Fig. 5). The dominant female of colony 6 (6a) showed a lower quantity of fat body than subdominant females, for instance, females $6 b$ and $6 c$. As mentioned, the dominant female of colony 5 was not analysed by morpho-physiological aspects because it disappeared before the collection.
Table IV. Classification matrix between predicted and observed classifications of inseminated (I) and uninseminated (NI) females after discriminant analysis in Mischocyttarus cassununga.

\begin{tabular}{llll}
\hline Pre-male & & & \\
Group & Percentage & $\mathrm{I}(\mathrm{n}=11), \mathrm{p}=0.3235$ & $\mathrm{NI}(\mathrm{n}=23), \mathrm{p}=0.6764$ \\
I & 27.27 & 3 & 8 \\
NI & 100.0 & 0 & 23 \\
Total & 76.47 & 3 & 31 \\
Post-male & & & \\
Group & Percentage & $\mathrm{I}(\mathrm{n}=13), \mathrm{p}=0.25$ & $\mathrm{NI}(\mathrm{n}=39), \mathrm{p}=0.75$ \\
I & 38.46 & 5 & 8 \\
NI & 94.87 & 2 & 37 \\
Total & 80.77 & 7 & 45 \\
\hline
\end{tabular}

Mutual tolerance among reproductive females. Our study demonstrates the presence of more than one inseminated female which would be able to lay diploids eggs in the colonies. Similar results were related by Oliveira (2007) in Mischocyttarus montei and Silva (2008) in Mischocyttarus cerberus styx. Unfortunately, we have not found solid indications that there is more than a single egg-laying wasp in the colonies, and that this is probably commonplace with $M$. cassununga. The behavioural data showed that almost all eggs (which were oviposited by more than one female per colony) had its development interrupted (by parasitism or by collection of colonies). On the other hand, we have obtained robust behavioural, morphological and physiological evidences implying that females of higher hierarchical positions could be taking part in the reproductive yield during the development of the colonies (Table V). The fact of inseminated females of higher hierarchically positions (potential reproductive females which were produced in the colony) remain in the colony rather than abandon it to found its own nest suggests a new aspect

Table V. Stage, substage, colony, ranked females that oviposited, destiny and number of time of oviposition in Mischocyttarus cassununga.

\begin{tabular}{|c|c|c|c|c|c|}
\hline Stage & Substage & Colony & $\begin{array}{l}\text { Individuals } \\
\text { and ranking } \\
\text { position }\end{array}$ & $\begin{array}{l}\text { Destiny } \\
\text { of eggs }\end{array}$ & $\begin{array}{l}\text { Number } \\
\text { of time }\end{array}$ \\
\hline \multirow{7}{*}{$\begin{array}{l}\text { Post- } \\
\text { emergence }\end{array}$} & \multirow[t]{5}{*}{ Pre-male } & 1 & $1^{\text {st }} 1^{\mathrm{a}}$ & Parasited & 4 \\
\hline & & & $2^{\text {nd }} 1 b$ & & 1 \\
\hline & & & $3^{\text {rd }} 1 \mathrm{c}$ & & \\
\hline & & 2 & $1^{\text {st }} \mathrm{ac}$ & $\begin{array}{l}\text { Oophagy and } \\
* \text { Interrupted }\end{array}$ & 2 \\
\hline & & 4 & $\begin{array}{l}2^{\text {nd }} \text { verm } \\
5^{\text {th }} \mathrm{vv} \\
2^{\text {nd }} \text { amv }\end{array}$ & Oophagy & 1 \\
\hline & \multirow[t]{2}{*}{ Post-male } & 5 & $\begin{array}{l}3^{\text {rd }} \text { amv } \\
4^{\text {th }} v e\end{array}$ & *Interrupted & 1 \\
\hline & & 6 & $\begin{array}{l}1^{\text {st }} \mathrm{am} \\
5^{\text {th }} \mathrm{azu} \\
2^{\text {nd }} \mathrm{vc} \\
3^{\mathrm{ve}} \mathrm{ve}\end{array}$ & $\begin{array}{l}\text { Oophagy and } \\
* \text { Interrupted }\end{array}$ & 1 \\
\hline
\end{tabular}


of the biology of M. cassununga. Similar result was related by Murakami \& Shima (2006), that is, the inseminated females of higher hierarchically positions just below the dominant female in the social ranking (sub-dominant females) are daughters which emerged from the colony and does not leave it. Based on this results we suggest that all females of higher hierarchically positions are probably daughters of dominant female. In the field of São Paulo State University - Campus of Rio Claro, the colonies of $M$. cassununga are predominantly founded by haplometrosis (personal observations), where there is a stable linear hierarchy during the colony development (Murakami \& Shima 2006). It also can help to explain the abundance of this species in the Campus during all season of year.

Finally, our study depicted partially a life strategy of $M$. cassununga that might account for an apparent edge over other species in the field (personal observations). The presence of more than one inseminated female with welldeveloped ovary, and the capacity of laying viable eggs increase the chances of success of the colony cycle. We would like to propose that this species should be regarded as a useful study model to understand the tolerance of more than one inseminated female in the same colony in post-emergence stage, pre-male substage of Mischocyttarus.

Acknowledgements. We thank Sidnei Mateus (Universidade de São Paulo) and Nivar Gobbi (Universidade Estadual Paulista) for their suggestion to this study, and Eduardo Fox for English corrections on the manuscript. This work was supported by the National Council for Scientific and Technological Development (CNPq).

\section{REFERENCES}

Deshpande, S. A.; A. Sumana; M. Surbeck \& R. Gadagkar. 2006. Wasp who would be queen: A comparative study of two primitively eusocial species. Current Science 91: 332-336.

Fukuda, H.; J-I. Kojima; K. Tsuchida \& F. Saito. 2003. Size-dependent reproductive dominance in foundresses of Ropalidia plebeiana, an Australian paper wasp forming nest aggregations (Hymenoptera: Vespidae). Entomological Science 6: 217-222.

Gobbi, N.; F. Noll \& M. A. Penna. 2006. "Winter" aggregations, colony cycle, and seasonal phenotypic chande in the paper wasp Polistes versicolor in subtropical Brazil. Naturwissenschaften 93: 487-497.

Jeanne, R. L. 1972. Social biology of neotropical wasp Mischocyttarus drewseni. Bulletin of the Museum of Comparative Zoology 144: $63-150$.

Jeanne, R. L. 1986. The evolution of the organization of work in social insects. Monitore Zoologico Italiano 20: 119-133.

Keeping, M. G. 2000. Morpho-physiological variability and differentiation of reproductive roles among foundresses of the primitively eusocial wasp, Belonogaster petiolata (Deeger) (Hymenoptera, Vespidae). Insectes Sociaux 47: 147-154.

Litte, M. 1977. Behavioral ecology of the social wasp Mischocyttarus mexicanus. Behavioral Ecology and Sociobiology 2: 229-312.

Litte, M. 1979. Mischocyttarus flavitarsus in Arizona: social and nesting biology of a polistine wasp. Zeitschrift fur Tierpsychologie 50: $282-312$.

Litte, M. 1981. Social biology of the polistine wasp Mischocyttarus labiatus: survival in a Colombia rain forest. Contributions to Zoology 317: 1-26.

Markiewicz, D. A. \& S. O’Donnell. 2001. Social dominance, task performance and nutrition: implications for reproduction in eusocial wasps. Journal of Comparative Physiology. Part A. Sensory, Neural, and Behavioral Physiology 187: 327-333. Murakami, A. S. N. \& S. N. Shima. 2006. Nutritional and social hierarchy establishment of the primitively eusocial wasp Mischocyttarus cassununga (Hymenoptera, Vespidae, Mischocyttarini) and related aspects. Sociobiology 48: 183-207.

Noda, S. C. M.; S. N. Shima \& F. B. Noll. 2003. Morphological and physiological caste differences in Synoeca cyanea (Hymenoptera,Vespidae,Epiponini) according to the ontogenetic development of colonies. Sociobiology 41: 547-569.

O'Donnell, S. 1998a. Reproductive caste determination in eusocial wasps (Hymenoptera: Vespidae). Annual Review of Entomology 43: $323-346$.

O'Donnell, S. 1998b. Dominance and polyethism in the eusocial wasp Mischocyttarus mastigophorus (Hymenoptera, Vespidae). Behavioral Ecology and Sociobiology 43: 327-331.

Oliveira, V. C. 2007. Diferenciação etológica e morfofisiológica das castas de Mischocyttarus (Monogynoecus) montei Zikàn, 1949 (Hymenoptera, Vespidae, Mischocyttarini), com especial referência à regulação social das colônias. Dissertação de mestrado. Universidade Estadual Paulista, Campus de Rio Claro. 159 p.

Paes de Oliveira, V. T. 2005. Relação entre o corpo gorduroso e a vitelogênese em fêmeas de Melipona quadrifasciata anthidioides Lep. Tese de doutoramento. Universidade Estadual Paulista, Campus de Rio Claro. 129 p.

Pardi, P. 1948. Dominance order in Polistes wasps. Physiological Zoology 21: 1-13.

Premnath, S.; K. Chandrashekara; S. Chandran \& R. Gadagkar. 1990. Constructing dominance hierarchies in a primitively eusocial wasp. In: The social insects and the Environment. XI International Congress- IUSSI Bangalore, Oxford \& IBH Publishing Co., New Delhi. <http://ces.iisc.ernet.in/hpg/ragh/publication_list/Gadagkar _Publications/Premnath_et_al_1990.pdf>. Access 08/06/2009.

Richards, O. W. 1971. The biology of the social wasp (Hymenoptera, Vespidae). Biological Review 46: 483-528.

Richards, O. W. 1978. The social wasps of America excluding the Vespinae. London, British Museum (Natural History), 580 p.

Richards, O. W. \& M. J. Richards. 1951. Observations on the social wasps of South America (Hymenoptera, Vespida).Transactions of the Entomological Society of London 102: 1-170.

Röseler, P. F. 1991. Reproductive competition during colony establishment, p. 311-333. In: K. G. Ross \& R. W. Matthews (eds.). The social biology of wasps. Ithaca, Cornell University Press, $696 \mathrm{p}$.

Röseler, P. F.; I. Röseler \& A. Strambi. 1985. Role of ovaries and ecdysteroids in dominance hierarchy establishment among foundresses of the primitively social wasp, Polistes gallicus. Behavioral Ecology and Sociobiology 18: 9-13.

Shima, S. N. 1991. Variabilidade das castas em algumas espécies de vespas sociais (Hymenoptera, Vespidae, Polybiini). Tese de Doutoramento. Universidade Estadual Paulista, Campus de Rio Claro. 234 p.

Shima, S. N.; S. Yamane \& R. Zucchi. 1994. Morphological caste differences in some Neotropical swarm-founding polistine wasps. I. Apoica flavissima (Hymenoptera,Vespidae). Japanese Journal of Entomology 62: 811-822.

Shima, S. N.; S. Yamane \& R. Zucchi. 1996a. Morphological caste differences in some Neotropical swarm-founding polistine wasps. II. Polybia dimidiata (Hymenoptera,Vespidae). Japanese Journal of Entomology 64: 131-144.

Shima, S. N.; S. Yamane \& R. Zucchi. 1996b. Morphological caste differences in some Neotropical swarm-founding polistine wasps. III. Protonectarina sylveirae (Hymenoptera,Vespidae). Bulletin of the Faculty of Education 42: 57-67.

Shima, S. N.; F. B. Noll; R. Zucchi \& S. Yamane. 1998. Morphological caste differences in the Neotropical swarm-founding Polistine wasps IV. Pseudopolybia vespiceps, with oreliminary considerations on the role of intermediate females in the social organization of the Epiponini (Hymenoptera, Vespidae). Journal of Hymenoptera 
Research 7: 280-295.

Shima, S. N.; F. B. Noll \& R. Zucchi. 2000a. Morphological caste difference in the neotropical swarm-founding polistine wasp, Brachygastra lecheguana (Hymenoptera,Vespidae,Epiponini). Sociobiology 36: 41-52.

Shima, S. N. S.; Yamane \& Y. Itô. 2000b. Morphological Caste Differences in the Australian swarm-founding wasp, Ropalidia romandi cabeti (Hymenoptera; Vespidae). Entomological Science 3: 73-79.

Shima, S. N.; F. B. Noll \& R. Zucchi. 2003. Influence of the colony cicle on physiological and morphological caste variation in the perennial neotropical swarm-founding social wasp, Protonectarina sylveirae (Hymenoptera, Vespidae,Epiponini). Sociobiology 42: 449-465.

Silva, I. M. 2008. Diferenciação etológica e morfofisiológica das castas de Mischocyttarus cerberus styx Richards, 1940 (Hymenoptera, Vespidae, Mischocyttarini), com especial referência à dinâmica do estabelecimento da hierarquia social. Dissertação de mestrado. Universidade Estadual Paulista, Campus de Rio Claro. 95 p.

Simões, D.; N. Gobbi \& B. R. M. Batarce. 1985. Mudanças sazonais na estrutura populacional em colônias de três espécies de vespas do gênero Mischocyttarus (Hymenoptera, Vespidae). Naturalia 10: 89-105.

Staurengo da Cunha, M. A. \& C. Cruz-Landim. 1983. Modificações histológicas e citoquímicas do corpo gorduroso de rainhas de Atta sexdens rubropilosa Forel (Hymenoptera, Formicidae) durante o primeiro ciclo reprodutivo. Acta Biológica Paranaense 12: 1122.
Strassmann, J. E. 1983. Nest fidelity and group size among foundresses of Polistes annularis (Hymenoptera: Vespidae). Journal of the Kansas Entomological Society 56: 621-634.

Strassmann, J. E. \& D. C. Meyer. 1983. Gerontocracy in the social wasp, Polistes exclamans. Animal Behaviour 31: 431-438.

Suzuki, T. 1987. Egg-producers in the colonies of a polistine wasp, Polistes snelleni (Hymenoptera: Vespidae), in central Japan. Ecological Research 2: 185-189.

Tannure-Nascimento, I. C.; F. S. Nascimento \& R. Zucchi. 2005. Size and colony cycle in Polistes satan, a Neotropical paper wasp (Hymenoptera, Vespidae). Ethology, Ecology and Evolution 17 105-119.

West-Eberhard, M. J. 1986. Dominance relations in Polistes canadensis (L.), a tropical social wasp. Monitore Zoologico Italiano 20 263-281.

Wheeler, D. E. 1986. Developmental and physiological determinants of caste in social Hymenoptera: Evolutionary implications. American Naturalist 128: 13-34.

Wheeler, D. 1994. Nourishment in ants: patterns individuals and societies, p. 245-278. In: J. H. Hunt \& C. A. Nalepa (eds.). Nourishment and evolution in insect societies. Westview, Boulder, $449 \mathrm{p}$.

Wheeler, D. 1996. The role of nourishment in oogenesis. Annual Review of Entomology 41: 407-431.

Zar, H. J. 1999. Biostatistical Analysis, fourth edition. New Jersey, Prentice-Hall International, $931 \mathrm{p}$

Received 21/08/2008; accepted 20/10/2009 